\title{
Nd-Sr isotopic determination of the ore-bearing Proterozoic ultramafic rocks in Jinchuan, China
}

\author{
JiE-DONG YANG, ${ }^{1}$ XIAN-CONG TAO, ${ }^{1}$ SHI-JIN XU ${ }^{2}$ and ZHONG-Li TANG ${ }^{3}$ \\ ${ }^{1}$ Center of Modern Analysis, Nanjing University, Nanjing, P.R.C. \\ ${ }^{2}$ Department of Earth Sciences, Nanjing University, Nanjing, P.R.C. \\ ${ }^{3}$ Bureau of Geology of Gansu Province, Lanzhou, P.R.C.
}

(Received April 8, 1993; Accepted December 3, 1993)

\begin{abstract}
Sm-Nd isotopic study for the ore-bearing Jinchuan ultramafic rocks in Gansu province, China, reveals the age of $1508 \pm 31 \mathrm{Ma}$, which is obtained by $\mathrm{Sm}-\mathrm{Nd}$ internal isochron method. The $\mathrm{Rb}-\mathrm{Sr}$ isotopic system of the Jinchuan rocks have been contaminated by crustal materials, but little influence of crustal materials disturbed their Sm-Nd isotopic system. The determined results for acid-washed pyroxenes show that the source region of the Jinchuan ultramafic rocks may possess the following features: relatively homogeneous negative $\varepsilon_{\mathrm{Nd}}(T)$ values, relatively dispersed $\varepsilon_{\mathrm{Sr}}(T)$ values (generally larger than +60 ), and exhibiting a horizontal distribution in Nd-Sr correlation diagram.
\end{abstract}

\section{INTRODUCTION}

The largest $\mathrm{Cu}-\mathrm{Ni}$ sulphide ore in China occurs in the Jinchuan ultramafic rocks, which are considered to have come initially from the subcontinental mantle. Because very few radiometric age data were published, the age of the Jinchuan rock body remains equivocal until now.

The major aims of the present study are: to determine age of the Jinchuan rock body using Sm-Nd method, which is, in generally, difficult to establish using other methods, and to obtain their initial $\mathrm{Nd}$ and $\mathrm{Sr}$ isotopic information.

\section{Geological Setting AND SAMPling LOCATIONS}

The Jinchuan rock body is located in about 30 $\mathrm{km}$ northeast of Yongcang city, Gangsu province, China. This area is on the upwarped district of margin of Alashan Platform at southwest SinoKorean Block and it belongs to the middle belt, inner of the Block being in its north and the corridor transition belt of the Qilian fold system being in its south (Sixth Team, 1984). The development of deep rifts in southern and northern flanks of the upwarped district formed two large rift zones. The upwarped district is mostly covered by the Precambrian strata consisting of the lower Baijiazuizi Formation and the upper Tamagouzi Formation. The Jinchuan ultramafic rock body has intruded in the Lower Proterozoic Baijiazuizi Formation with shape of dyke along the rift in northern flank, and is in discordant contact with gneiss, marble and migmatite. The rock body is $6500 \mathrm{~m}$ in length and 30 to $500 \mathrm{~m}$ in width, emerging an area of $1.34 \mathrm{~km}^{2}$, and composed mostly of peridotites with high abundance Ni (Fig. 1). Some researchers thought that the Jinchuan rocks were derived initially from mantle, rose along a supercrust fault zone and then reached a magma chamber in crust. Finally, they went into the present position under action of pulsating tectonic stress (Sixth Team, 1984).

The minerals in the ultramafic samples are mostly olivines (mainly chrysolytes) and pyroxenes (mainly clinopyroxenes) with a small amount of plagioclases, sulfides and metallic minerals. Under microscope, olivines are generally alterated into serpophites and fibred taxoites, and a part of py- 


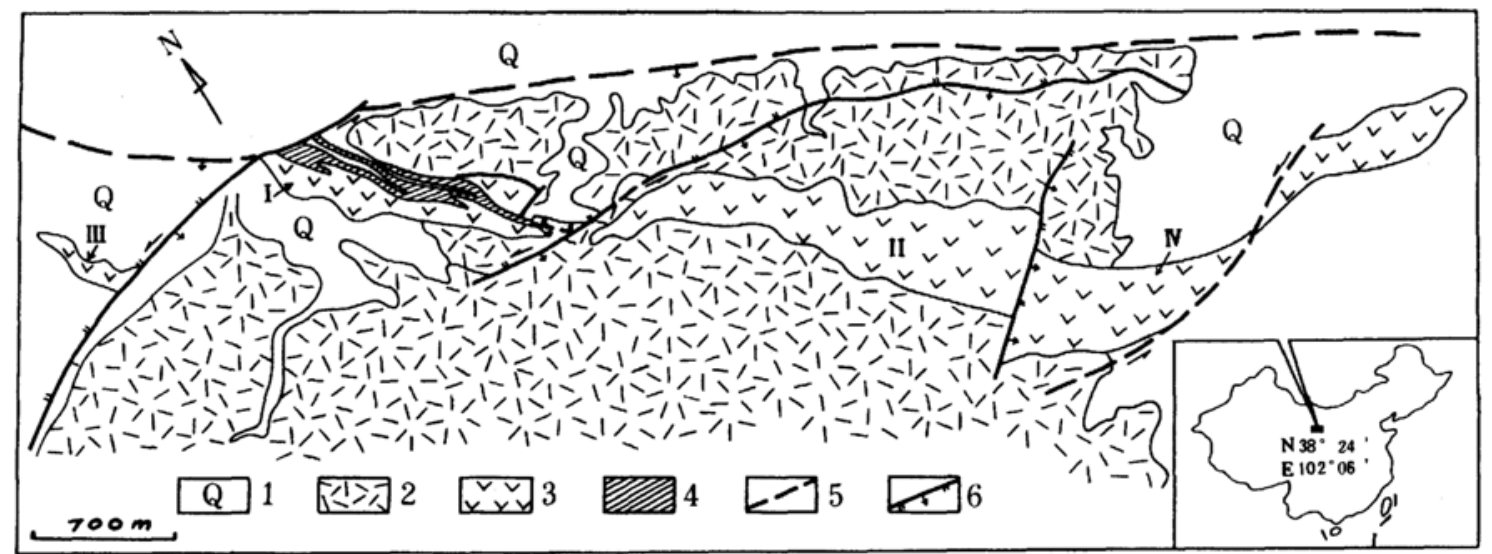

Fig. 1. Geological map of the Cu-Ni sulphide ore district of Baijiazuizi. 1: Quaternary system, 2: Precambrian migmatites, 3: ultramafic rocks, 4: emergenced area of ore bodies, 5: deep rifts, 6: faults.

Table 1. Mineral compositions of the Jinchuan ultramafic rocks

\begin{tabular}{llccc}
\hline Sample No. & \multicolumn{1}{c}{ Rock type } & $\begin{array}{c}\text { Olivine } \\
\text { (wt.\%) }\end{array}$ & $\begin{array}{c}\text { Pyroxene } \\
\text { (wt.\%) }\end{array}$ & $\begin{array}{c}\text { Plagioclase and } \\
\text { others (wt.\%) }\end{array}$ \\
\hline JA-9 & lherzolite & 65 & 30 & 5 \\
JA-9b & augite-peridotite & 60 & 36 & 4 \\
JA-9c & augite-peridotite & 65 & 30 & 5 \\
JA-7a & lherzolite & 55 & 40 & 5 \\
JII-1 & lherzolite & 55 & 40 & 5 \\
JII-36 & olivine pyroxenite & 30 & 70 & 0 \\
JII-37 & pyroxenolite & 7 & 90 & 3 \\
JII-50 & lherzolite & 55 & 30 & 15 \\
JII-66 & augite-peridotite & 55 & 40 & 5 \\
JII-69 & lherzolite & 50 & 35 & 15 \\
JII-73 & augite-peridotite & 55 & 35 & 10 \\
\hline
\end{tabular}

roxenes were alterated into amphioboles. The mineral compositions of the Jinchuan ultramafic rocks is listed in Table 1.

\section{EXPERIMENTAL METHOD}

The whole rock samples (about $5 \mathrm{~kg}$ each) were split into small fragments (about $1 \mathrm{~cm}$ ). After ultrasonically cleaned in distilled water, they were crushed and sieved. A portion of 0.1 to $1 \mathrm{~mm}$ in size was used for mineral separation, which was executed repeatedly by heavy liquid and magnetic separation techniques. The separates were further purified by hand-picking under a binocular microscope and rejecting those grains showing signs of alteration.

It has been shown repeatedly that the acidwashed method can successfully remove $\mathrm{Nd}$ and Sr not hosted in the pyroxene structure, which are predominantly of crustal origin. The superficial contaminant should not affect the isotopic compositions of clean clinopyroxene separates, even in highly altered rocks of spinel and garnet facies (Zindler et al., 1983; Reisberg, 1988; Reisberg et al., 1989). So, in the present study, the key analyses were performed on hand-picked, acidwashed pyroxene separates from samples JA-9, JII50, JII-66 and JII-69.

The acid-washed procedure is as the following: Samples were placed in $3 \mathrm{~N} \mathrm{HCl}$ for 3 hours. Two 
times during this period the $\mathrm{HCl}$ leachate was changed and samples were agitated for about 15 minutes in an ultrasonic bath. Next, they were leached in $10 \% \mathrm{HF}$ in an ultrasonic bath for several minutes and then washed in ultrapure water several times. After treated as above, sample weights were only about one half of the original untreated samples.

$\mathrm{Nd}, \mathrm{Sr}, \mathrm{Sm}$ and $\mathrm{Rb}$ concentrations were determined using the MSID method. Sample powders ( $<200$ mesh) for isotopic analysis were spiked with ${ }^{145} \mathrm{Nd},{ }^{149} \mathrm{Sm},{ }^{84} \mathrm{Sr}$ and ${ }^{87} \mathrm{Rb}$ tracers prior to digestion to ensure spike equilibration. Following the initial open beaker evaporation, they were decomposed with $\mathrm{HF}+\mathrm{HClO}_{4}$ in teflon bombs for two days at a temperature of about $200^{\circ} \mathrm{C}$. After the samples were removed from the oven, $\mathrm{HClO}_{4}$ was added and evaporated to dryness. $6 \mathrm{~N} \mathrm{HCl}$ was added several times until samples were completely dissolved and solution showed clear.

Two sets of cation exchange columns (AG50 WX-8 resin, 200-400 mesh) were used in chemical procedure. $\mathrm{Sr}, \mathrm{Rb}$ and total REE were separated and collected in the first set. The separation of $\mathrm{Sm}$ and $\mathrm{Nd}$ were carried out using the second set and $0.23 \mathrm{M} \alpha$-hydroxyisobutyric aid at ph 4.43 as eluant. $\mathrm{Rb}$ and $\mathrm{Sr}$ were loaded onto single Ta filaments, while $\mathrm{Sm}$ and $\mathrm{Nd}$ onto Ta-Re-Ta triple filaments for analysis on a VG 354 mass spectrometer with 5-collector at Nanjing University. Fractionations were corrected by normalizing to a ${ }^{86} \mathrm{Sr} /{ }^{88} \mathrm{Sr}$ value of 0.1194 and ${ }^{146} \mathrm{Nd} /{ }^{144} \mathrm{Nd}$ value of 0.7219 . ${ }^{147} \mathrm{Sm} /{ }^{144} \mathrm{Nd}$ value was limited to $<5 \times$ $10^{-4}$ when $\mathrm{Nd}$ isotopic ratios were measured. $\mathrm{Nd}$ isotopic ratios of each sample were directly determined using the unspiked samples. Uncertainties in concentrations of $\mathrm{Sm}$ and $\mathrm{Nd}$ were $\leqslant 0.1 \%$. During this study, an average obtained for NBS $987{ }^{87} \mathrm{Sr} /{ }^{86} \mathrm{Sr}$ ratios was $0.71023 \pm 1$. The results measured for BCR-1 and La Jolla are ${ }^{148} \mathrm{Nd} /{ }^{144} \mathrm{Nd}$ $=0.512662 \pm 9$ and $0.511860 \pm 4$, respectively. Typical total-procedure blank levels are $0.06 \mathrm{ng}$ for $\mathrm{Nd}$ and $1 \mathrm{ng}$ for $\mathrm{Sr}$. The experimental details have been described by Wang et al. (1988).

$\varepsilon_{\mathrm{Nd}}(T)$ and $\varepsilon_{\mathrm{Sr}}(T)$ were calculated using the equations as previously defined by DePaolo and
Wasserburg (1976, 1977). The present-day bulk earth (CHUR) values used were: ${ }^{148} \mathrm{Nd} /{ }^{144} \mathrm{Nd}=$ 0.512638 and ${ }^{147} \mathrm{Sm} /{ }^{144} \mathrm{Nd}=0.1967$ (Jacobsen and Wasserburg, 1980; Wasserburg et al., 1981). The present-day total earth (UR) values used were: ${ }^{87} \mathrm{Sr} /$ ${ }^{86} \mathrm{Sr}=0.7045$ and ${ }^{87} \mathrm{Rb} /{ }^{86} \mathrm{Sr}=0.0827$ (DePaolo, 1981). The decay constants used were: $6.54 \times$ $10^{-12} \mathrm{a}^{-1}$ for ${ }^{147} \mathrm{Sm}$ and $1.42 \times 10^{-11} \mathrm{a}^{-1}$ for ${ }^{87} \mathrm{Rb}$. Isochrons were statistically calculated using the computer program of two-error regression with reciprocal of square of error as weight (Model 2) in the book of Faure (1988).

\section{RESUlts AND DISCUSSION}

Age of the Jinchuan ultramafic rock body

$\mathrm{Sm}-\mathrm{Nd}$ and $\mathrm{Rb}-\mathrm{Sr}$ isotopic results for the Jinchuan rocks are listed in Tables 2 and 3, respectively.

Because of the nowly-proven ability of the Sm$\mathrm{Nd}$ radiometric system to provide precise chronological information for mafic and ultramafic rocks that have suffered severe $\mathrm{Rb}-\mathrm{Sr}$ redistribution, the $\mathrm{Sm}-\mathrm{Nd}$ internal isochron method was used in the present study. From Table 1, the whole rock samples have very close $\mathrm{Sm} / \mathrm{Nd}$ and $\mathrm{Nd}$ isotopic ratios and they can not yield a reliable isochron. However, the mineral separates and their whole rocks from which the minerals were isolated show a sufficient variation in $\mathrm{Sm} / \mathrm{Nd}$ and $\mathrm{Nd}$ isotopic ratios to obtain isochrons. Four internal isochrons consisting of the whole rocks and pyroxenes (PY(G) and PY(B)) from samples JA-9, JII-50, JII66 and JII-69 are plotted in Fig. 2, respectively, which give very close ages of $1540 \pm 45 \mathrm{Ma}, 1534$ $\pm 32 \mathrm{Ma}, 1488 \pm 77 \mathrm{Ma}$ and $1515 \pm 97 \mathrm{Ma}$. By combining JII-50, JII-66 and JII-69 of the second group (lherzolite), all eight points give a well defined isochron with the age of $1508 \pm 31 \mathrm{Ma}$, with relative coefficient of 0.999 and MSWD of 0.33 (Fig. 3). The age of combining eight points of the second group (lherzolite) is in correspondance with four ages obtained respectively. Each acid-washed pyroxene has the same ${ }^{147} \mathrm{Sm} /{ }^{144} \mathrm{Nd}$ and ${ }^{148} \mathrm{Nd} /$ ${ }^{144} \mathrm{Nd}$ ratios as that of unwashed pyroxene, and they all fall on the original isochrons. So, the 
Table 2. Sm-Nd isotopic results of the Jinchuan rocks

\begin{tabular}{|c|c|c|c|c|c|c|c|}
\hline Sample No. & Rock type a & $\mathrm{Sm}(\mathrm{ppm})$ & Nd (ppm) & ${ }^{147} \mathrm{Sm} /{ }^{144} \mathrm{Nd}$ & ${ }^{143} \mathrm{Nd} /{ }^{144} \mathrm{Nd}^{\mathrm{b}}$ & $\varepsilon_{\mathrm{Nd}}(T)^{\mathrm{c}}$ & Group \\
\hline \multirow[t]{3}{*}{ JA-9 } & lherzolite & 0.6211 & 2.948 & 0.1270 & $0.511800 \pm 10$ & -2.9 & 1 \\
\hline & Py (G) & 1.984 & 7.658 & 0.1562 & $0.512095 \pm 9$ & -2.8 & \\
\hline & awp & 1.811 & 7.592 & 0.1498 & $0.512021 \pm 11$ & -3.0 & \\
\hline JA-9b & augite-peridotite & 0.1251 & 0.597 & 0.1266 & $0.511780 \pm 50$ & -3.2 & 1 \\
\hline JA-9c & augite-peridotite & 0.2163 & 1.005 & 0.1282 & $0.511801 \pm 27$ & -3.1 & 1 \\
\hline $\mathrm{JA}-7 \mathrm{a}$ & lherzolite & 0.1810 & 0.836 & 0.1302 & $0.511810 \pm 42$ & -3.3 & 2 \\
\hline JII-1 & lherzolite & 0.5931 & 2.849 & 0.1258 & $0.511790 \pm 17$ & -2.8 & 2 \\
\hline \multirow[t]{2}{*}{ JII-36 } & olivine & & & & & & \\
\hline & pyroxenite & 1.705 & 7.970 & 0.1288 & $0.511826 \pm 22$ & -2.7 & 2 \\
\hline JII-37 & pyroxenolite & 2.044 & 9.350 & 0.1318 & $0.511830 \pm 36$ & -3.2 & 2 \\
\hline \multirow[t]{4}{*}{ JII-50 } & lherzolite & 1.584 & 6.985 & 0.1366 & $0.511854 \pm 10$ & -3.7 & 2 \\
\hline & Py (G) & 2.660 & 10.37 & 0.1550 & $0.512039 \pm 8$ & -3.6 & \\
\hline & Py (B) & 2.496 & 10.31 & 0.1466 & $0.511948 \pm 9$ & -3.7 & \\
\hline & awp & 2.511 & 10.12 & 0.1477 & $0.511955 \pm 12$ & -3.6 & \\
\hline \multirow[t]{4}{*}{ JII-66 } & augite-peridotite & 1.886 & 8.317 & 0.1366 & $0.511859 \pm 7$ & -3.6 & 2 \\
\hline & Py $(G)$ & 2.607 & 10.24 & 0.1540 & $0.512032 \pm 7$ & -3.6 & \\
\hline & Py (B) & 2.427 & 9.713 & 0.1511 & $0.511993 \pm 9$ & -3.7 & \\
\hline & awp & 2.461 & 9.921 & 0.1553 & $0.512004 \pm 11$ & -3.6 & \\
\hline \multirow[t]{3}{*}{ JII-69 } & lherzolite & 1.537 & 6.778 & 0.1366 & $0.511860 \pm 10$ & -3.6 & 2 \\
\hline & Py (G) & 3.627 & 13.73 & 0.1598 & $0.512091 \pm 11$ & -3.5 & \\
\hline & awp & 3.583 & 13.41 & 0.1606 & $0.512122 \pm 9$ & -3.1 & \\
\hline JII-73 & augite-peridotite & 1.102 & 5.102 & 0.1306 & $0.511827 \pm 11$ & -3.0 & 2 \\
\hline
\end{tabular}

${ }^{a} G$ : high-quality separates, awp: acid-washed pyroxenes, B: slightly poor separates, Py: pyroxenes.

${ }^{b}$ Data normalized to ${ }^{146} \mathrm{Nd} /{ }^{144} \mathrm{Nd}=0.7219$, error: $2 \sigma \mathrm{m}$.

${ }^{c}$ Calculated for $\mathrm{T}=1508 \mathrm{Ma}$.

Table 3. Rb-Sr isotopic results of the Jinchuan rocks

\begin{tabular}{|c|c|c|c|c|c|c|c|c|}
\hline Sample No. & Rock type ${ }^{a}$ & $\mathrm{Rb}(\mathrm{ppm})$ & $\mathrm{Sr}(\mathrm{ppm})$ & ${ }^{87} \mathrm{Rb} /{ }^{86} \mathrm{Sr}$ & ${ }^{87} \mathrm{Sr} /{ }^{86} \mathrm{Sr}^{\mathrm{b}}$ & $\left({ }^{87} \mathrm{Sr} /{ }^{86} \mathrm{Sr}\right)_{\mathrm{i}}$ & $\varepsilon_{\mathrm{Sr}}(T)^{\mathrm{c}}$ & Group \\
\hline \multirow[t]{3}{*}{ JA-9 } & lherzolite & 5.61 & 27.0 & 0.600 & $0.71689 \pm 4$ & 0.70390 & +17.0 & 1 \\
\hline & awr & 3.10 & 19.8 & 0.489 & $0.71481 \pm 2$ & 0.70423 & +21.6 & \\
\hline & awp & 0.51 & 2.60 & 0.471 & $0.71736 \pm 50$ & 0.70716 & +63.4 & \\
\hline \multirow[t]{3}{*}{ JII-36 } & olivine & & & & & & & \\
\hline & pyroxenite & 9.61 & 49.4 & 0.563 & $0.71472 \pm 2$ & 0.70254 & -2.3 & 2 \\
\hline & awr & 5.91 & 47.0 & 0.363 & $0.71252 \pm 2$ & 0.70465 & +27.7 & \\
\hline \multirow[t]{3}{*}{ JII-50 } & lherzolite & 10.0 & 178 & 0.166 & $0.71044 \pm 2$ & 0.70685 & +58.9 & 2 \\
\hline & awr & 7.11 & 157 & 0.130 & $0.70914 \pm 2$ & 0.70632 & +51.4 & \\
\hline & awp & 2.13 & 67.2 & 0.102 & $0.71027 \pm 2$ & 0.70806 & +76.2 & \\
\hline \multirow[t]{3}{*}{ JII-66 } & augite-peridotite & 18.5 & 108 & 0.496 & $0.71329 \pm 6$ & 0.70256 & -2.1 & 2 \\
\hline & awr & 6.41 & 78.5 & 0.236 & $0.71217 \pm 11$ & 0.70707 & +62.0 & \\
\hline & awp & 3.21 & 104 & 0.089 & $0.71072 \pm 2$ & 0.70879 & +86.1 & \\
\hline \multirow[t]{3}{*}{ JII-69 } & lherzolite & 10.0 & 162 & 0.179 & $0.71220 \pm 6$ & 0.70832 & +80.8 & 2 \\
\hline & awr & 8.71 & 183 & 0.138 & $0.70947 \pm 3$ & 0.70650 & +53.9 & \\
\hline & awp & 1.61 & 37.5 & 0.123 & $0.71200 \pm 5$ & 0.70933 & +94.1 & \\
\hline \multirow[t]{2}{*}{ JII-73 } & augite-peridotite & 3.80 & 26.8 & 0.410 & $0.71321 \pm 2$ & 0.70433 & +23.1 & 2 \\
\hline & awr & 2.20 & 20.1 & 0.316 & $0.71321 \pm 2$ & 0.70628 & +50.9 & \\
\hline
\end{tabular}

${ }^{a}$ awr: acid-washed whole rocks, awp: acid-washed pyroxenes.

${ }^{b}$ Data normalized to ${ }^{86} \mathrm{Sr} /{ }^{88} \mathrm{Sr}=0.1194$, error: $2 \sigma \mathrm{m}$.

${ }^{c}$ Calculated for $\mathrm{T}=1508 \mathrm{Ma}$. 

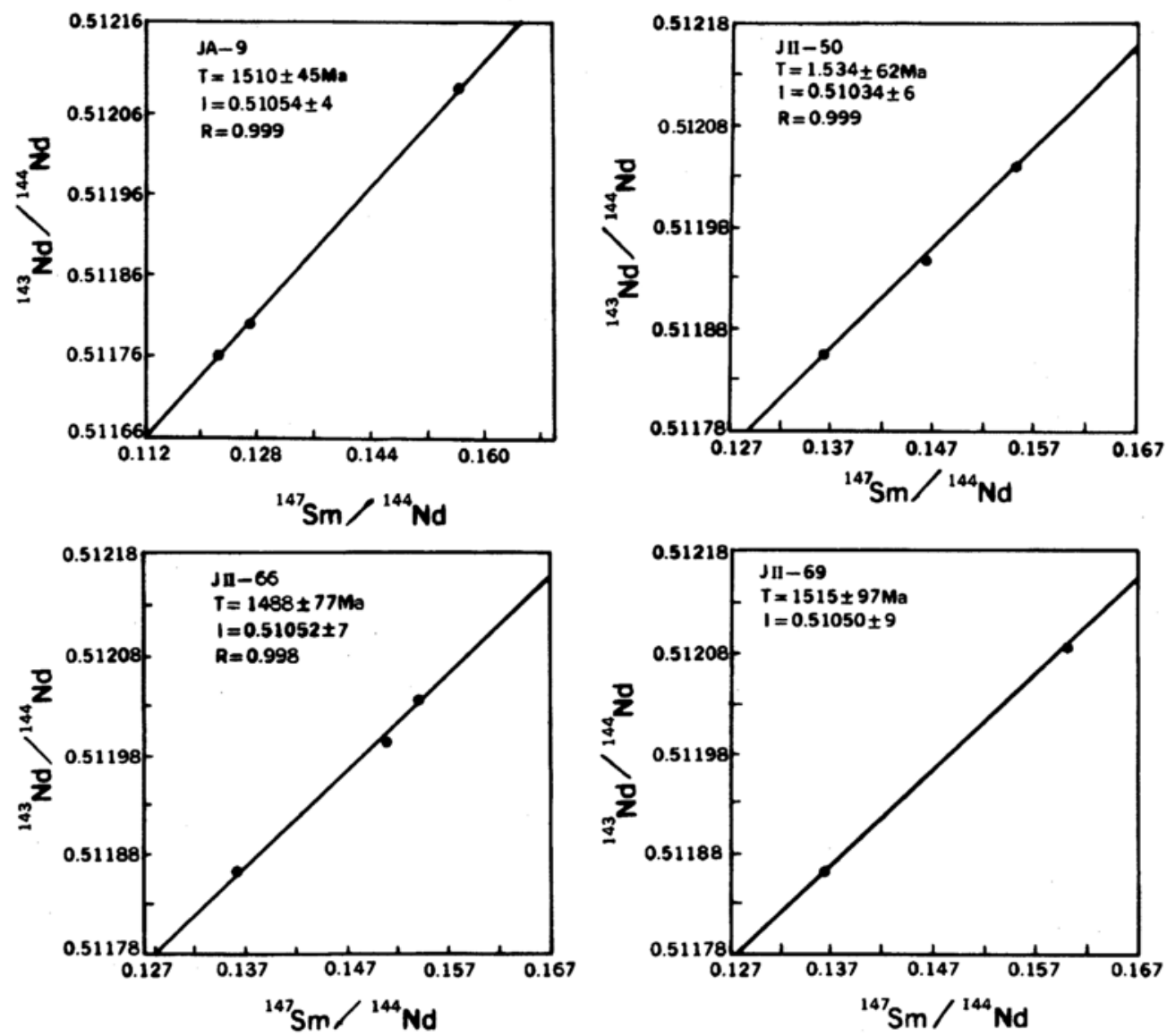

Fig. 2. Sm-Nd internal isochrons for samples JA-9, JII-50, JII-66 and JII-69.

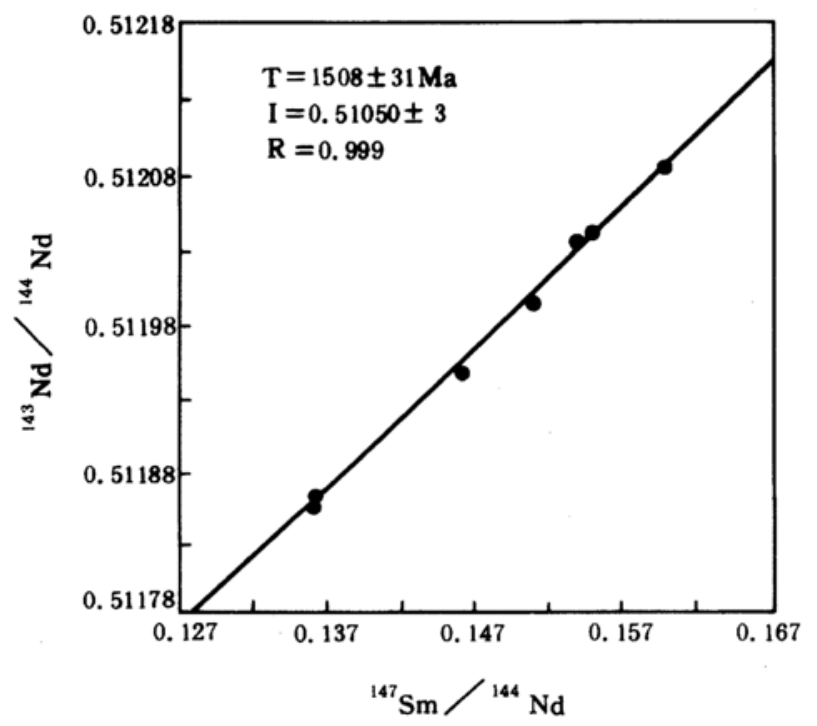

Fig. 3. Sm-Nd isochron defined by combining samples JII-50, JII-66 and JII-69 of second group. 
combining age of $1508 \pm 31 \mathrm{Ma}$ can be considered to represent the crystallization age of the Jinchuan ultramafic rock body.

\section{$\mathrm{Nd}$-Sr isotopic correlativity}

In Table 2, Sm and $\mathrm{Nd}$ concentrations of the whole rocks are obviously lower than those of pyroxenes, meaning that pyroxenes are the main minerals rich in REE. From the calculation with time $(T)$ of $1508 \mathrm{Ma}$, the $\varepsilon_{\mathrm{Nd}}(T)$ values of all samples, whatever are the whole rocks, unwashed pyroxenes or acid-washed pyroxenes, are very close, falling within -2.7 and -3.7 . Indeed, these values can be considered to be identical because the experimental errors are about \pm 0.5 . The experimental results indicate that little influence of contamination of crustal source disturbed the Sm and $\mathrm{Nd}$ isotopic system of the Jinchuan samples. The $\varepsilon_{\mathrm{Nd}}(T)$ values of determined samples may reflect the Sm-Nd isotopic character of the source region of the Jinchuan rock body.

In contrast to the undisturbed evidence in the $\mathrm{Sm}-\mathrm{Nd}$ system, $\mathrm{Rb}-\mathrm{Sr}$ isotopic data (Table 3) demonstrate the following tendency for unwashed

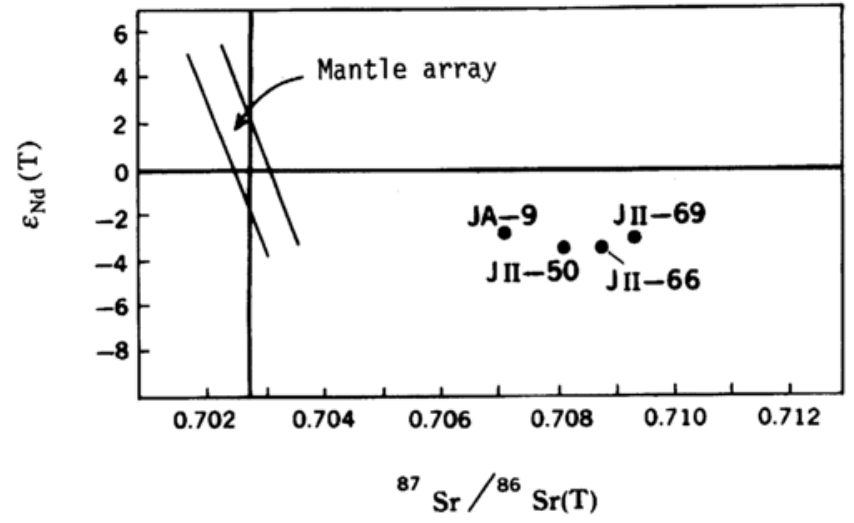

Fig. 4. Nd-Sr isotopic distribution of pyroxenes in Jinchuan rocks in $\mathrm{Nd}$-Sr correlation diagram $(T=1508 \mathrm{Ma})$.

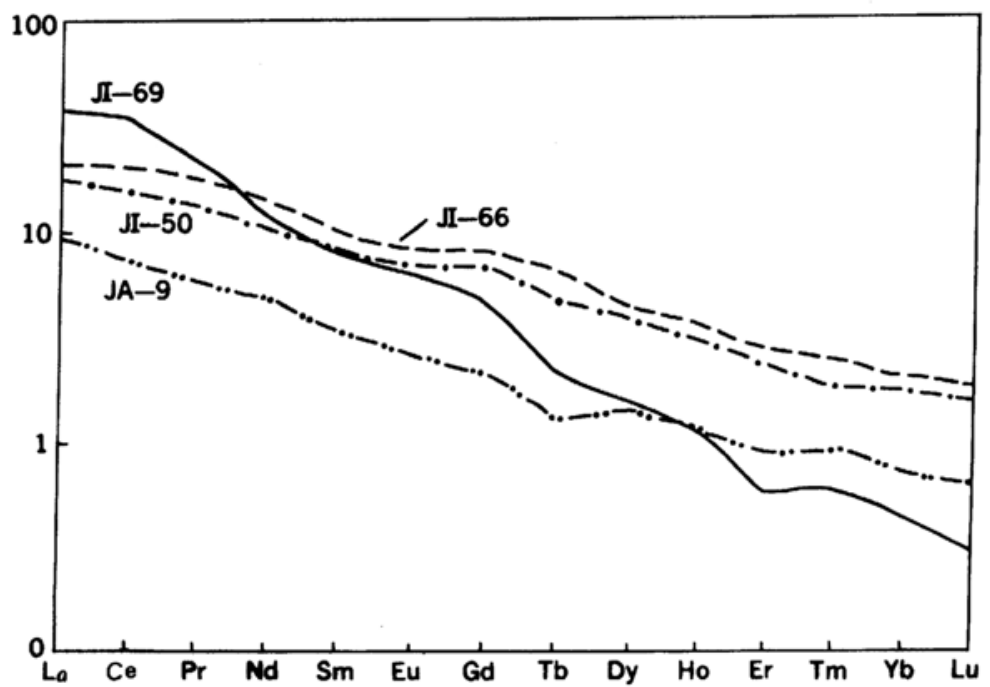

Fig. 5. REE patterns for samples JA-9, JII-50, JII-66 and JII-69 normalized to chondritic values (Wakita et al., 1971). 
whole rocks (uwr) and acid-washed whole rocks (awr):

$$
\begin{aligned}
& \text { (conc. of } \left.\mathrm{Rb}, \mathrm{Sr})_{\mathrm{uwr}}>\text { (conc. of } \mathrm{Rb}, \mathrm{Sr}\right)_{\mathrm{awr}} \text {, } \\
& (\mathrm{Rb} / \mathrm{Sr})_{\mathrm{uwr}}>(\mathrm{Rb} / \mathrm{Sr})_{\mathrm{awr}} \text {, and } \\
& \left(\varepsilon_{\mathrm{Sr}}(T)\right)_{\mathrm{uwr}}<\left(\varepsilon_{\mathrm{Sr}}(T)\right)_{\mathrm{awr}} .
\end{aligned}
$$

This clearly indicates that the $\mathrm{Rb}-\mathrm{Sr}$ isotopic system of the whole rocks has been subjected to contamination of crustal materials. The $\varepsilon_{\mathrm{Sr}}(T)$ values of acid-washed pyroxenes are better values close to the true $\varepsilon_{\mathrm{Sr}}(T)$ of source region from which the Jinchuan rocks were derived. The $\varepsilon_{\mathrm{Sr}}(T)$ values of the source region certainly are positive and, in general, larger than +60 .

The analysis of Nd-Sr isotopic correlation is one of the important methods to investigate nature of source. Figure 4 shows the distribution of four acid-washed pyroxenes, extracted from samples JA-9, JII-50, JII-66 and JI-69, respectively, in the $\mathrm{Nd}-\mathrm{Sr}$ correlation diagram. The four points all fall in the quarter IV and they align on a horizontal line.

Rere earth elements for the four samples (JA9, JII-50, JII-66 and JII-69) are plotted in Fig. 5. They show similar LREE-enriched patterns.

Through the discussion above, the Jinchuan ultramafic rocks may have come from a source region demonstrating these features of $\mathrm{Nd}-\mathrm{Sr}$ isotopes:

a. relatively homogeneous $\varepsilon_{\mathrm{Nd}}(T)$ values (mostly in $-3.2 \pm 0.5$ ),

b. relatively dispersed $\varepsilon_{\mathrm{Sr}}(T)$ values (mostly larger than +60 ),

c. horizontal distribution in the Nd-Sr correlation diagram, and

d. rich in LREE.

\section{CONCLUSIONS}

Three conclusions can be obtained from the present study. The first is that the age of the Jinchuan ultramafic rock body is $1508 \pm 31 \mathrm{Ma}$, which is gained by the $\mathrm{Sm}-\mathrm{Nd}$ internal isochron method. The second is that $\mathrm{Rb}-\mathrm{Sr}$ isotopic system of the Jinchuan rocks has been evidently contaminated by crustal materials, but little influence of crustal source disturbed their Sm-Nd isotopic system. The third is that the source region of the Jinchuan ultramafic rocks may possess the features of $\mathrm{Nd}-\mathrm{Sr}$ isotopes: relatively homogeneous negative $\varepsilon_{\mathrm{Nd}}(T)$ values, relatively dispersed $\varepsilon_{\mathrm{Sr}}(T)$ values, in general, larger than +60 , and exhibiting a horizontal distribution in the $\mathrm{Nd}-\mathrm{Sr}$ correlation diagram.

Acknowledgments-This work has been supported by the Foundation of National Laboratory for Metalliferous Ore and Metallogenetic Action of Nanjing University and the Foundation of Center of Modern Analysis, Nanjing University.

\section{REFERENCES}

DePaolo, D. J. (1981) A neodymium and strontium isotopic study of the Mesozoic cale-alkaline granitic batholiths of the Sierra Nevada and Peninsular Ranges, California. J. Geophys. Res. 86, 1047010488.

DePaolo, D. J. and Wasserburg, G. J. (1976) Nd isotopic variations and petrogenetic models. Geophys. Res. Lett. 3, 249-252.

DePaolo, D. J. and Wasserburg, G. J. (1977) The sources of island arcs as indicated by $\mathrm{Nd}$ and $\mathrm{Sr}$ isotopic studies. Geophys. Res. Lett. 4, 465-468.

Faure, G. (1988) Principle of Isotope Geology. 464-465, John Wiley and Sons, New York.

Jacobsen, S. B. and Wasserburg, G. J. (1980) Sm-Nd isotopic evolution of chondrites. Earth Planet. Sci. Lett. 50, 139-155.

Reisberg, L. (1988) The isotopic and geochemical systematics of the Ronda ultramafic complex of southern Spain. Ph.D. Thesis, Columbia University.

Reisberg, A., Zindler, A. and Jagoutz, E. (1989) Further $\mathrm{Sr}$ and $\mathrm{Nd}$ isotopic results from peridotites of the Ronda ultramafic complex. Earth Planet. Sci. Lett. 96, 161-180.

Sixth Team in Gansu (1984) Geology of the $\mathrm{Cu}-\mathrm{Ni}$ Sulphide Ore of Baijiazuizi. Geological Publishing House, Beijing, China (in Chinese).

Wakita, H., Rey, P. and Schmitt, R. A. (1971) Abundances of the 14 rare-earth elements and 12 other trace-elements in Apollo 12 samples: five igneous and one braccia rocks and four soils. Proc. 2nd Lunar Sci. Conf., 1319-1329.

Wang, Y. X., Yang, J. D., Tao, X. Ch. and Li, H. M. 
(1988) A study of the Sm-Nd method for fossil, mineral and its applications. J. Nanjing Univ. 24(2), 297-308 (in Chinese).

Wasserburg, G. J., Jacobsen, S. B., DePaolo, D. J. and McCulloch, M. T. (1981) Precise determination of $\mathrm{Sm} / \mathrm{Nd}$ ratios, $\mathrm{Sm}$ and $\mathrm{Nd}$ isotopic abundances in standard solutions. Geochim. Cosmochim. Acta 45, 2311-2323.

Zindler, A., Staudigel, H., Hart, S. R., Endres, R. and Goldstein, S. (1983) Nd and $\mathrm{Sr}$ isotopic study of a mafic layer from Ronda ultramafic complex. Nature 304, 226-230. 